\title{
Innovation in the Teaching-Learning Process through a MOOC: Sustainability in the Era of Big Data
}

\author{
Gago-Cortés, Carmen ${ }^{1 ;}$ Alló, Maria²; Longarela-Ares, Ángeles 3 ; Mourelle, Estefanía ${ }^{4}$ \\ ${ }^{1}$ Universidade da Coruña, Facultade de Economía e Empresa, 0000-0002-5670-968X \\ ${ }^{2}$ Universidade da Coruña, Facultade de Economía e Empresa, 0000-0003-1389-7235 \\ ${ }^{3}$ Universidade da Coruña, Facultade de Economía e Empresa, 0000-0003-0488-4950 \\ ${ }^{4}$ Universidade da Coruña, Facultade de Economía e Empresa, 0000-0002-7420-9830
}

\section{RESUMEN}

La interacción entre la importante preocupación mundial en torno al desarrollo sostenible y el rápido crecimiento tecnológico ha dado como resultado el diseño de un curso abierto masivo en línea (MOOC) sobre Sostenibilidad en la era del Big Data. Este proyecto se enmarca en una convocatoria pionera lanzada por la Universidade da Coruña (UDC) (España) en 2018. Su objetivo principal es crear un espacio para difundir, concienciar y promover el desarrollo sostenible en sus tres dimensiones: ambiental, social y económica. Mediante el uso de herramientas basadas en la web, el conocimiento se comparte con un amplio público, sin necesidad de conocimientos previos. Para motivar a los estudiantes, el MOOC fue diseñado como una historia basada en un mundo distópico, la cual les permite involucrarse, desarrollar sus habilidades digitales y mejorar su aprendizaje sobre la sostenibilidad. Se proponen también diferentes desafíos aplicables al mundo real basados en el enfoque de gamificación, así como debates entre estudiantes. Asimismo, se ha realizado un cuestionario en línea para conocer el grado de compromiso de los participantes con la sostenibilidad al comienzo del curso y en su evaluación final. Su realización reveló la buena recepción de esta iniciativa, además de la generación de conciencia y conocimiento. Estos resultados fomentan el desarrollo de acciones similares, centradas en herramientas innovadoras.

PALABRAS CLAVE: educación, educación en línea, MO0C, innovación, sostenibilidad. 


\section{CITA RECOMENDADA:}

Gago-Cortés, Carmen; Alló, Maria; Longarela-Ares, Ángeles; Mourelle, Estefanía (2020): Innovation in the Teaching-Learning Process through a MOOC: Sustainability in the Era of Big Data. En De la Torre Fernández, E. (ed.) (2020). Contextos universitarios transformadores: Boas prácticas no marco dos GID. IV Xornadas de Innovación Docente. Cufie. Universidade da Coruña. A Coruña (págs. 107-120). DOI capítulo: https://doi.org/10.17979/spudc. 9788497497756.107 DOl libro: https://doi.org/10.17979/spudc. 9788497497756

\section{ABSTRACT}

The interaction between the worldwide major concern on sustainable development and the rapid technological growth resulted in the design of a massive online open course (MOOC) on Sustainability in the Era of Big Data. This project is engaged in a pioneer call launched by the Universidade da Coruña (UDC) (Spain) in 2018. Its main goal was to create a space to publicize, raise awareness and promote sustainable development in its three dimensions: environmental, social and economic. By using webbased tools, knowledge is open and shared with a wide audience, without previous knowledge needed. To engage students, the MOOC was designed as a storytelling based on a dystopian world where they get involved, developing their digital skills, and improving their learning about sustainability. Different challenges applicable in real-world based on the gamification approach, as well as debates between students, were proposed. An online questionnaire was carried to know the degree of commitment of the participants with sustainability at the beginning of the course, and at their final assessment. Its completion revealed the good reception of this initiative, besides raising awareness and knowledge. These results encourage the development of similar actions, focused on innovative tools.

KEY WORDS: education, e-learning, MOOC, innovation, sustainability. 


\section{INTRODUCTION}

The different earth's ecosystems have suffered a severe deterioration since the 60 s due to human activity. There is a clear need for a change of individual and collective attitude to stop this problem, raising concern and awareness about it. The society is starting to become more responsible at this respect, as people must learn to live together following sustainable principles (UNESC0, 2013). In this context, education comes into play as a major actor for achieving a sustainable development; education will make it possible to turn learners into agents of change, making the problem visible, raising awareness and, ultimately, correcting it. The United Nations Decade of Education for Sustainable Development focuses on reshaping the educational systems to address the social, economic and environmental dimensions of sustainable development (Lenglet, Fadeeva, \& Mochizuki, 2010) by enhancing the examination of relevant information, critical thinking and development of practices and applied actions (Wiek, Withycombe, \& Redman, 2011).

Therefore, educational institutions, in particular Higher Education ones, play a major role in generating and extending knowledge, besides becoming more active and responsible actors in their socioeconomic environments (the so-called third mission of the University) (Trippl, Sinozic, \& Lawton Smith, 2015). In this sense, they are incorporating sustainable development actions in their systems and curricula (Leal Filho et al., 2019), formulating policy statements and creating initiatives like Green Campus programs; the inclusion of sustainability in curricula, teaching and research is essential. However, the real application of the third mission has not been fully conceptualized at the present time (Molas-Gallart \& Castro-Martínez, 2007); education for sustainability skills are seldom completely integrated in Higher Education Institutions (HEls).

Therefore, it is necessary to go beyond and reach the visibility of the HEls' actions in the context they are located. At this respect, one should bear in mind the society in which we live, the network society (Castells, 1996), characterized by the extraordinary technological progress and the rapid changing scenarios. This transformation of the society is also reflected in education at all levels, where there must be an adaptation to changing needs and changing 
learners (Lai, 2011). This gives rise to non-traditional types of learning, ranging from blended learning to learning based on any number of technological resources.

Our work is the result of the interaction between the worldwide major concern on sustainable development and the rapid technological growth: the design of a massive online open course (MOOC) on Sustainability in the Era of Big Data (hereinafter, SEBD). MOOCs are offered by virtual platforms and have experienced a massive increase in recent years with positive results; compared to the traditional scenario, this type of distance education allows for sharing knowledge with a wider audience (Greenhow, Robelia, \& Hughes, 2009). In fact, this strength is one of the foundations of the MOOC we carried out at the Universidade da Coruña (UDC).

The SEBD MOOC emerged as an initiative of a group of lecturers in economics and business, members of the Green Campus Environmental Committee from the Faculty of Economics and Business (UDC), in collaboration with the University Center for Training and Educational Innovation (CUFIE) from the same institution. The course is framed within the pioneer project for creating MOOCs in the UDC, whose first call was launched in 2018, and was included within the Curriculum Greening of Higher Education of the University.

The aim of this project is twofold. First, the urgent need for raising awareness and promoting sustainable development in its three dimensions (environmental, social and economic), as well as increasing the visibility of this problem. Second, by means of its free access, to provide basic knowledge on sustainability and the Big Data application to this area in order to reach the largest possible audience. Harnessing of information and Big Data constitutes a tool for achieving the objectives of the triple bottom line policies and the institutional strategies.

The SEBD MOOC was finally released in 2019 , lasting from June the 17 th to July the 14 th, with the support of the Miríadax platform. It was opened to a wide audience without requiring previous knowledge. The next sections go into detail on the creation, development and assessment of the course. Accordingly, section two describes the experience of the SEBD MOOC, section three is dedicated to the results and, finally, section four presents the main conclusions of this work. 


\section{DESCRIPTION OF THE MOOC EXPERIENCE}

\subsection{ORIGINS}

This project started with the first call for MOOCs from the UDC, launched by the University Center for Training and Educational Innovation (CUFIE) in February 2018. The project emerged within the Green Campus Environmental Committee of the Faculty of Economics and Business. Thus, when the MOOC call was launched, the members of teaching staff used synergies and a double motivation. On the one hand, all the members were very aware of sustainable development, so that the dissemination of concepts on the subject was considered a key point to preserve our ecosystem. And, on the other hand, the project became part of the actions to be carried out by the Faculty of Economics and Business in order to achieve the Green Campus Green Flag.

The teaching staff consisted of two coordinators and three lecturers for giving the lessons. The first edition of the course was held from June the $17^{\text {th }}$ to July the $14^{\text {th }} 2019$ and a second edition is planned for early 2020 .

\subsection{MOOC DESCRIPTION}

The course is structured in three modules that cover contents related to environmental (module 1), social (module 2) and economic sustainability (module 3). Next, we will discuss the course objectives and the skills that students can acquire, the development and design of the course, the materials necessary to carry it out, the contents and the evaluation system.

\subsubsection{COURSE OBJECTIVES AND COMPETENCES}

The main focus of the course was the involvement of the students in the teaching-learning process, the visibility of the problem and raising public awareness, the development of knowledge about sustainability and big data, and the expansion of the digital skills of the 
students. Therefore, the course has training objectives as well as environmental awareness objectives.

Regarding the training objectives, each module has its own objectives, but the objectives of one module are related to the other ones following the same structure. Module 1 introduces the meaning of ecosystem services and their importance in sustainable development, studies the different methods of economic valuation of ecosystem services and determines why Big Data can be useful for developing more effective environmental policies. Module 2 seeks to know the main theories about human development and its main indicators, to know how this development can be favoured from the public sector and to distinguish the different ways in which Big Data can be used for more efficient and sustainable social development policies. Module 3 it is intended to raise awareness of development and economic inequality concepts, as well as their causes, consequences and possible solutions; to approach production and consumption models from a sustainable perspective and from the institutional, business and consumer point of view, and understand the usefulness of Big Data in the implementation of sustainable initiatives in the economic field.

With respect to the objectives of environmental awareness, it is intended that students consider the current situation, how we arrived here and what future awaits us. In this way, they get involved in their learning process and in the care of their environment.

In addition, apart from increasing their knowledge in the field of sustainability and Big Data, and their environmental awareness through the completion of this course, students acquire and improve several skills such as increasing their autonomy in the learning process through a selfregulated learning (SRL) (Carrera \& Ramírez-Hernández, 2018; Vilkova, 2019; Wang, Shannon, \& Ross, 2013; Zimmerman, 1998), being able to manage the times and space of study, and combine it with other occupations, always with the support of the teaching staff. Moreover, it improves their digital skills, since it is an online course that requires managing a platform and a social network. Finally, it fosters their critical and analytical capacity by means of discussions 
with colleagues from around the world that enables them to expand their vision of the surrounding environment.

\subsubsection{DEVELOPMENT, DESIGN AND MATERIALS NEEDED}

To carry out this project, the teaching staff had the collaboration and support of the CUFIE technical team. The teaching staff was responsible for the design of the course, the development of contents, the implementation of the course and the dynamization in social networks, while the technical team was responsible for recording and editing the videos, as well as the graphic design of materials, the release of the course, the support of the dynamization through social networks and the design of promotional material (t-shirts and cloth bags).

The SEBD MOOC was released through the Miríadax platform, which is mainly present in Latin America but also reaches other countries such as the United States, France, Italy or even India. This allowed for reaching a large number of students and making the course massive, online and open. The platform itself has a forum from which the participation of students can be boosted, but following the recommendations of the technical team, a Twitter account was also opened, @sasemooc, from which this dynamization has been complemented.

To make the course more attractive, a story was created with the objective of involving the student in its own learning process through storytelling (Andrews, Hull, \& Donahue, 2009) and gamification (Mena, Rincón-Flores, Ramírez, \& Ramírez-Montoya, 2018; Teixes, 2014). As it is a course on sustainability, the teaching staff raised a question as a starting point to create the storytelling: what would happen if we still do not take care of our ecosystem? The answer, if everything continues as before, gave rise to a dystopian, futuristic and very different version of the city of A Coruña in 2050: Nova Crunia. In Nova Crunia, climate change has caused some of its emblematic areas to be flooded by the sea, and pollution reaches such a high level that closing it with a dome and purify the air inside have been necessary. In addition, socioeconomic inequalities have escalated to an extent that the poorest population in the city has 
been expelled, leaving only one elite residing inside them, who produce and consume excessively. The large population expelled has been grouped around three clans; the Ocean clan, led by Erik, the Forest clan, led by Ruth, and the Grotto clan, led by Emma. These heroes are fighting to get an open and equitable city.

This storytelling is designed for students to focus on helping heroes to achieve their goal, using the contents of the course. At the beginning of the course, students were invited to enter in a Playbuzz test' where, by answering several questions, they can find out which clan they belong to and identify with it. Then, each clan was associated with one of the three modules of the course: the module dedicated to the environment was assigned the 0cean clan, the module dedicated to social sustainability, the Forest clan, and to the economic module it was assigned the Grotto clan. The modules correspond to the three areas that make up the concept of sustainable development, and these contents have been adapted to all kinds of audiences, so it was not necessary to have prior knowledge.

\subsubsection{CONTENTS AND EVALUATION SYSTEM}

As for the contents of the course, they are structured in three modules that follow the same pattern: first, the basic concepts related to each area are shown and how Big Data can be used as effective tool for the development of more effective and sustainable policies; secondly, they are presented with a knowledge test; and thirdly, a challenge is posed. Module 1 specifically focuses on ecosystem services and their valuation and has the challenge of sharing news related to climate change via Twitter or via the course forum. Module 2 focuses on human development and its indicators, and its challenge is to share a photograph of an impoverished neighbourhood in the area where the student resides. Module 3 focuses on economic inequality and sustainable production and consumption models, and its challenge is to upload a photograph of a consumption, reuse or recycling habit. And as a final challenge, the students were asked to finish their story, proposing a solution for their hero to fulfil the goal on the basis of the knowledge acquired in the course. 
The evaluation of each module consisted of a mandatory and a voluntary part based on SRL and challenge-based learning (CBL), respectively (Carrera \& Ramírez-Hernández, 2018; Vilkova, 2019; Wang et al., 2013; Zimmerman, 1998). The mandatory part consisted of a sixquestion test with three options that were carried out at the end of each module, and the voluntary part was to overcome the mentioned challenges, what help to engage the students, to reduce the possibility they leave the course and can favor higher test scores and improves students' performance in online teaching (Mena et al., 2018).

\section{RESULTS OF THE EXPERIENCE}

In this section we provide some results in order to highlight two main issues: the level of commitment with sustainability of the participants and their evaluation of the course. To do this, two online surveys were conducted among students. First of all, it is important to note that the SEBD MOOC achieved a total of 1,318 registered students; 736 of them started the course and 377 completed it. This means a completion rate of almost $29 \%$, which can be considered a successful result compared with other previous experiences (Burd, 2015). The main explanation may be due to the free content of the course and the fact that it is taught at a basic level and therefore is accessible to all audiences. In addition, advanced Big Data tools are placed at the service of ecosystem preservation and sustainable socio-economic development. Kalman (2014) suggests that the main attraction of MOOCS is to provide a free access and high-level content.

The first questionnaire shared with the students had as a main goal to know the reasons why they took part of this course, as well as previous experiences with online courses, but above all, the key point was to analyse their level of awareness regarding environmental, social and economic problems faced nowadays by our society. The last section of the survey also contained some questions regarding sociodemographic characteristics of students. The second questionnaire was designed to know the perception that students had about the design of the course, among other more technical aspects. 
Results obtained with the first survey shown that about $41 \%$ of participants were women and that the average age of the sample was around 42 years old. Attending to the level of education attained, $74 \%$ commented that they have university studies. Regarding the geographical location of the students, around 45\% were living in Europe, 41\% in South America, 9\% in North America and $5 \%$ in Central America.

The main reasons argued to participate in this online course were that this is a "topic that interests me" (86\%), "to expand my knowledge" (8\%), "it's a free course" (5\%) and "because they have recommended it to me" (1\%). In addition, around $83 \%$ of students had previous experience with this kind of education.

Focusing our attention in questions related to level of awareness of the participants with respect to sustainable development, we included a set of questions in order to know who they think that are the main responsible of the current problems. Results show that when taking of climate change or pollution, students thinks that the general society is the main responsible. However, when asking about problems like social or economic inequalities or energy poverty, the main responsible are governments and political parties. It is also important to note that more than $90 \%$ of participants agreed with the idea that their countries should act against the abovementioned problems.

Deeping now into the more technical aspects of the course, it is important to comment that when asking about what kind of tools have been more useful for their learning, students mentioned that the most important were: the documents presented on video (21\%), documents on video and extra-materials (24\%), and all the material together with the activities played in forums (15\%). Therefore, results suggest that the use and development of videos is an attractive tool to spread and share knowledge. In addition, the most valuated content by the participants was the organization of the information (70\%), the use of simple and ease materials $(13 \%)$, the use of clear videos (11\%), the use of visuals, graphics, etc. (4\%), and finally, the functioning of the platform (2\%). 
To evaluate their level of learning, the course included evaluation questionnaires. At this regard, above the $75 \%$ of the students affirmed that they were correct, $21 \%$ mentioned that they were dense and $4 \%$ found that they were insufficient. Moreover, about the perception of the course, around $77 \%$ answered that it was accessible, 19\% mentioned that it was quite easy and $4 \%$ a little complicated. In summary, around $85 \%$ mentioned that the learning pace was excellent and what is even more important, $97 \%$ of the sample affirmed that they have learned.

Finally, some conclusions can be highlighted, thus, the use of videos is highly appreciated by students together with the use of traditional theoretical material. Therefore, through the conduction of these questionnaires we can point out that there is a positive evaluation of this kind of online education. Moreover, results obtained are in line with the main conclusions suggested by previous studies (Carrera \& Ramírez-Hernández, 2018).

\section{CONCLUSIONS}

Growing ecological awareness, coupled with the appearance of new procedures of data collection and processing that can be applied for promoting better sustainable development, are the driving forces behind the SEBD MOOC. This combination of pertinent topics has been the key to achieving broad acceptance of this course. The storytelling created for this MOOC has also played a fundamental role in engaging and motivating students. This innovative tool has enabled the staging of a dystopian future that allows participants to be aware of the most challenging issues facing our society if more sustainable policies do not begin to be applied. Indeed, the creation, graphic design, and animation of this storytelling were precisely the hardest tasks of this course. The coordination between the teaching staff and the technical team has been essential for the correct fulfilment of the course. For this reason, this aspect should continue to be promoted in successive editions, favouring an environment of productive exchange of ideas and work. Another great challenge to overcome has been the recording and editing of the videos that collect the contents of the course. Given the lack of initial experience and considering that it is one of the aspects most valued by the participants, improving the 
quality and originality of these videos is one of the main aspects that both lecturers and technical team wish to improve for the future.

The voluntary challenges launched through the forums can also be improved in order to promote greater interaction from the participants. The first challenge of sharing news related to climate change has been better accepted and has generated greater participation both on Twitter and in the forum of the course. Therefore, the rest of the proposed challenges can be designed in this way to try to achieve similar participation. And, given the importance of the feedback information provided by the participants through the questionnaires, the design of the questions can also be improved to facilitate an easier, faster and more accurate response. In this way, it is about increasing the number of people who provide information through these instruments.

All these changes can make this course reach more and more people, who will be able through it to implement more sustainable actions for our planet.

The use of the innovative tools indicated has been essential for achieving the goals and purposes of this course. Therefore, continuing in this line and promoting the use of these types of teaching tools is highly recommended for all those who wish to achieve similar results.

\section{REFERENCES}

Andrews, D. H., Hull, T. D., \& Donahue, J. A. (2009). Storytelling as an Instructional Method: Definitions and Research Questions. Interdisciplinary Journal of Problem-Based Learning, 3(2)10.7771/1541-5015.1063

Burd, E. L. (2015). Exploring business models for MOOCs in higher education. Innovative Higher Education, 40(1), 37. 10.1007/s10755-014-9297-0

Carrera, J., \& Ramírez-Hernández, D. (2018). Innovative Education in MOOC for Sustainability: Learnings and Motivations. Sustainability, 10(9), 2990.

Castells, M. (1996). The information age: Economy, society and culture (3 volumes). Blackwell, Oxford, 1997, 1998. 
Greenhow, C., Robelia, B., \& Hughes, J. E. (2009). Learning, teaching, and scholarship in a digital age: Web 2.0 and classroom research: What path should we take now? Educational Researcher, 38(4), 246-259.

Kalman, Y. M. (2014). A race to the bottom: MOOCs and higher education business models. Open Learning, 29(1), 5. 10.1080/02680513.2014.922410

Lai, K. (2011). Digital technology and the culture of teaching and learning in higher education. Australasian Journal of Educational Technology, 27(8)

Leal Filho, W., Vargas, V. R., Salvia, A. L., Brandli, L. L., Pallant, E., Klavins, M., . . Conticelli, E. (2019). The role of higher education institutions in sustainability initiatives at the local level. Journal of Cleaner Production, (233), 1004-1015.

Lenglet, F., Fadeeva, Z., \& Mochizuki, Y. (2010). ESD promises and challenges: Increasing its relevance. Global Environment Research, 14(2), 93-100.

Mena, J. J., Rincón-Flores, E. G., Ramírez, R., \& Ramírez-Montoya, M. S. (2018). The use of gamification as a teaching methodology in a MOOC about the strategic energy reform in México10.1007/978-3-319-98872-6. Retrieved from https://link.springer.com/chapter/10.1007/978-3-319-98872-6_4

Molas-Gallart, J., \& Castro-Martínez, E. (2007). Ambiguity and conflict in the development of 'Third Mission'indicators. Research Evaluation, 16(4), 321-330.

Teixes, F. (2014). Gamificación: fundamentos y aplicaciones. Cataluña, Spain: Editorial UOC.

Trippl, M., Sinozic, T., \& Lawton Smith, H. (2015). The Role of Universities in Regional Development: Conceptual Models and Policy Institutions in the UK, Sweden and Austria. European Planning Studies, 23(9), 1722-1740. 10.1080/09654313.2015.1052782

UNESCO. (2013). Education for Sustainable Development. Retrieved from https://en.unesco.org/themes/education-sustainable-development

Vilkova, K. (2019). Self-regulated learning and successful MOOC completion. Retrieved from http://ceur-ws.org/Vol-2356/research_short12.pdf 
Wang, C., Shannon, D. M., \& Ross, M. E. (2013). Students' characteristics, self-regulated learning, technology self-efficacy, and course outcomes in online learning. Distance Education, 34(3), 302-323.

Wiek, A., Withycombe, L., \& Redman, C. L. (2011). Key competencies in sustainability: a reference framework for academic program development. Sustainability Science, 6(2), 203-218.

Zimmerman, B. J. (1998). Academic studing and the development of personal skill: A selfregulatory perspective. Educational Psychologist, 33(2-3), 73-86.

i Available at https://www.playbuzz.com/laupasi10/test-a-qu-clan-perteneces 